\title{
Contraction of the composite skin graft and autograft
}

\author{
Alfredo Gragnani MD PhD ${ }^{1}$, Jeffrey R Morgan $\mathrm{PhD}^{2}$, Lydia Masako Ferreira MD PhD ${ }^{1}$
}

\begin{abstract}
A Gragnani, JR Morgan, LM Ferreira. Contraction of the composite skin graft and autograft. Can J Plast Surg 2002;10(4):155-157.

Wound contraction as a result of a delay in grafting or second intention healing in an area that there was no graft take is a serious problem because of the sequela to the burned patient.

The objective of the present study was to evaluate the contraction of the cultured keratinocytes and human acellular dermis composite graft by tracing the graft with transparent film after transplantation to the back of athymic mice.

The evaluation of the contraction of the composite skin grafts and autografts in relation to the original wound area on the back of the athymic mice demonstrated greater contraction of the grafts after the dressings were removed on the seventh day. The composite skin graft contraction was significantly bigger than the autograft contraction.

The experimental data suggested that the contraction appeared after dressing removal, but that the macroscopic aspect of the composite skin graft remained normal with no distortion of the graft or the surrounded murine skin.
\end{abstract}

Key Words: Contraction; Graft; Skin

\section{Contraction du greffon cutané combiné et de l'autogreffe}

RÉSUMÉ : La contraction d'une plaie par suite d'un retard de la greffe ou d'un phénomène de cicatrisation de seconde intention dans une zone où le greffon n'a pas pris est un problème grave en raison des séquelles qu'elle laisse chez les grands brûlés.

L'objectif de la présente étude était d'évaluer la contraction d'un greffon combiné à base de kératinocytes mis en culture et de derme acellulaire humain en traçant le contour du greffon au moyen d'une pellicule transparente après transplantation sur le dos d'une souris athymique.

L'évaluation de la contraction des greffons cutanés combinés et des autogreffes par rapport à la zone originale de la lésion sur le dos de souris athymiques a permis de démontrer une contraction plus grande des greffons après le retrait des pansements le septième jour. La contraction du greffon cutané combiné a été significativement plus importante que celle de l'autogreffe.

Les données expérimentales donnent à penser que la contraction s'est manifestée après le retrait du pansement, mais que l'aspect macroscopique du greffon cutané combiné est resté normal, sans distorsion du greffon ni de la peau murine avoisinante.
$\mathrm{E}$ arly excision and skin replacement are performed to treat patients with burns. When sufficient donor sites exist, autograft is the chosen procedure for skin restoration. However, when donor sites are sparse, standard skin autografting procedures are not sufficient, and biological substitutes should be used for skin replacement (1).

The use of the cultured epithelial sheet with approximately two to eight cell layers of thickness has a low rate of graft take, and there is a long period until the restoration of the basement membrane is completed. The need for dermis in the skin substitute is essential and it must be present in the composite substitute (2).

Research of bioengineered skin substitutes includes a combination of cultured skin cells and dermal analogs. Definitive wound closure is achieved when human acellular dermis is used in the composite skin graft (3).

Many investigations showed that different kinds of grafts showed distinct limitations in their performance, related mainly to wound contraction and fragility of the epidermis. Wound contraction as the result of a delay in grafting or

${ }^{1}$ Department of Plastic Surgery, Federal University of São Paolo, São Paolo, Brazil; 2 Shriners Hospital for Children, Boston, Massachusetts 
second intention healing in an area that there was no graft take is a serious problem because it is a cause of morbidity in burned patients.

The objective of the present study was to evaluate the contraction of cultured keratinocytes and human acellular dermis composite graft by tracing the graft with transparent film after transplantation to the back of athymic mice.

\section{Culture of human cells}

\section{MATERIALS AND METHODS}

Normal human keratinocytes derived from neonatal foreskins were isolated and cultured following the methods described by Green et al (4). In each grafting experiment, all keratinocytes were derived from a single foreskin. To initiate cultures, keratinocytes were cocultivated with 3T3-J2 mouse fibroblasts (provided by $\mathrm{H}$ Green, Harvard Medical School, USA) and pretreated with $15 \mu \mathrm{g} / \mathrm{mL}$ mitomycin C (Boehringer Mannheim, USA).

Keratinocyte culture media, which was changed every three to four days, was a three to one mixture of high-glucose Dulbecco's Modified Eagle's medium (DMEM) and Ham's F12 medium (Gibco BRL, USA), supplemented with $10 \%$ fetal bovine serum and prepared according to Green's protocol (4). Swiss mouse 3T3-J2 cells were routinely passaged in high-glucose DMEM, supplemented with 10\% bovine calf serum (Hyclone, USA) and penicillin-streptomycin $(100 \mathrm{IU} / \mathrm{mL}$ to $100 \mu \mathrm{g} / \mathrm{mL})$, and incubated in a humidified $10 \% \mathrm{CO}_{2}$ atmosphere at $37^{\circ} \mathrm{C}$.

\section{Preparation of acellular dermis}

Human cadaver skin with an average thickness of $0.03 \mathrm{~cm}$ was obtained from the Shriners Burn Hospital skin bank (Boston, Massachusetts). It had been cryopreserved according to the bank's protocol using glycerol and controlled rate freezing, and was cytomegalovirus-, Hepatitis B- and HIVnegative. To separate the epidermis from the dermis and to render the dermis acellular, the skin was subjected to three rapid freeze/thaw cycles in liquid nitrogen to devitalize the cells, was washed three times in sterile phosphate buffered saline (PBS), and was incubated at $37^{\circ} \mathrm{C}$ for one week in sterile PBS with antibiotics (gentamycin at $100 \mu \mathrm{g} / \mathrm{mL}$, ciprofloxacin at $10 \mu \mathrm{g} / \mathrm{mL}$, amphotericin B at $2.5 \mu \mathrm{g} / \mathrm{mL}$, and penicillin-streptomycin at $100 \mathrm{IU} / \mathrm{mL}$ to $100 \mu \mathrm{g} / \mathrm{mL}$ ). After this, the epidermis was able to be stripped gently from the dermis with forceps. The dermis was maintained for four weeks in antibiotic solution at $4^{\circ} \mathrm{C}$ to remove any remaining cells.

\section{Composite skin grafts}

Before use, the acellular dermis was washed three times with DMEM to remove residual antibiotics. The acellular dermis was cut into 1.25 to $1.5 \mathrm{~cm}^{2}$ pieces, and each piece was placed into a $35 \mathrm{~mm}$ tissue culture dish, with the papillary side facing up. Third passage cultured keratinocytes in KCM were seeded onto the surface of each piece of dermis $\left(2.5 \times 10^{5} \mathrm{cells} / \mathrm{cm}^{2}\right)$, and the composite grafts were maintained in culture for 10 days before grafting.
After three days of submersion, the experimental grafts were raised to the air-liquid interface on steel mesh screens for four weeks (5).

\section{Transplantation of composite grafts}

Grafting was performed in a laminar flow hood using five- to eight-week-old National Institutes of Health Swiss nu/nu mice (Taconic Farms, USA) that were anesthetized with an intraperitoneal injection of 2,2,2-tribromoethanol (0.58 $\mathrm{mg} / \mathrm{g}$ body weight) (Aldrich, USA). The dorsum of each mouse was washed with a $70 \%$ ethanol and betadine solution. Scissors were used to create a full-thickness (including panniculus carnosus), $1.5 \mathrm{~cm}^{2}$ defect down to the fascia of the dorsal musculature. The composite skin graft was placed on the wound, trimmed to fit precisely in the defect, and traced with transparent film.

The graft was secured with a 6-0 nylon stitch at each corner. Triple antibiotic ointment was applied to two stacked pieces of Telfa no-stick gauze (Kendall Co, USA), and the pieces were applied to the graft and secured with 6-0 nylon sutures. A skin adhesive (Benzoin; Ferndale Lab, USA) was applied to the mouse skin around the wound, and one half of a $5 \times 6.5 \mathrm{~cm}$ piece of Tegaderm brand polyurethane occlusive dressing (3-M, USA) was applied over the Telfa dressing.

The graft was also dressed with a trimmed 3-M Sports Band-Aid (3-M, USA), which was placed over the Tegaderm. A $1 \mathrm{~cm}$ wide piece of waterproof adhesive tape (Johnson \& Johnson, USA) was wrapped around the mouse to cover the dressing. All bandages were changed four days after the transplantation and the wound was left without dressing at seven days. This early dressing removal was adopted because the composite skin grafts were well differentiated before transplantation by lifting them to air-liquid interface and by using Ponec's medium. Five composite skin grafts and three autografts were transplanted.

Measurements of the area traced with transparent film were made at four, seven, 10, 14, 17, 21, 24, 28 and 31 days after the transplantation, in composite skin grafts and autografts, and studied by computer image scanning of the trace. At each time, the grafts were photographed. The statistical analysis was made by $t$-test, with significance accepted at the $95 \%$ confidence level $(\mathrm{P}<0.05)$.

\section{RESULTS}

The contraction evaluation showed greater contraction between the seventh and 10th day after transplantation, and remained stable until the end of the experiment. The composite skin graft contraction was greater than that of the autograft, relative to the original wound area. At 31 days after transplantation, which marked the end of the experiment, the average area of the composite skin grafts was $44.24 \%$ of the original wound area, and the average area of the autografts was $81 \%$ (Figure 1).

The first dressing removal was made four days after transplantation, and the final dressing removal was at seven days, after which the animals were able to touch the grafts. 
The macroscopic aspect of the grafts at 31 days after transplantation demonstrated that the contraction, pigmentation and desquamation of the skin graft was bigger in the composite skin grafts than in the autografts (Figure 2 ).

\section{DISCUSSION}

Banks-Schlegel and Green (6) made 108 cultured grafts and showed early primary take six days after transplantation, but the grafts were very fragile. In control animals in which a $2 \times 2 \mathrm{~cm}$ graft bed was made but no graft was applied, complete epidermis was formed over the graft bed by migrated mouse epidermal cells within nine to 10 days. Whether grafted or not, the wound contracted progressively. In animals grafted with human epithelium, contraction was inhibited somewhat, but the final size of the wound was generally about $1.5 \times 3 \mathrm{~cm}$.

As clearly demonstrated for pure epidermal grafts in the rabbit by Billingham and Reynolds (7), contracture of the graft bed was very extensive, so that the final area covered by human epidermis was much less than the epithelium grafted area.

Medalie et al (8) demonstrated that after an initial phase of contraction of composite skin grafts during the first six weeks, the grafts were stable, durable and well tolerated by the animals.

Boyce et al (9) showed that bed graft size after cultured skin transplantation was not statistically different than that treated with human skin, murine autograft and bed graft with no graft. They used dressing without irrigation and the contraction after six weeks with no graft was $20 \%$ of the original size, while human skin graft was $50 \%$ of the original size.

Boyce et al (10) evaluated the use of topical irrigants on cultured composite grafts in athymic mice and concluded that this promoted graft take and inhibited graft contraction.

Boyce et al (11) demonstrated that the composite skin graft and the murine autograft showed no statistical difference of contraction relative to the original wound area, but after the animals were removed from their dressings at four weeks, the contractions of both were more than $50 \%$ of the original wound area.

\section{REFERENCES}

1. Tompkins RG, Burke JF. Alternative wound coverings.

In: Herndon DN. Total Burn Care. Philadelphia: WB Saunders, 1996:164-72.

2. Compton CC. Wound healing potential of cultured epithelium. Wounds 1993;5:97-111.

3. Morgan JR, Yarmush ML. Bioengineered skin substitutes. Sci Med 1997;4:6-15.

4. Green H, Kehinde O, Thomas J. Growth of cultured human epidermal cells into multiple epithelia suitable for grafting. Proc Natl Acad Sci USA 1979;76:5665-9.

5. Ponec M, Weerheim A, Kempenaar J, et al. The formation of component barrier lipids in reconstructed human epidermis requires the presence of vitamin C. J Invest Dermatol 1997;9:348-55.

6. Banks-Schlegel S, Green H. Formation of epidermis by serially cultivated human epidermal cells transplanted as an epithelium to athymic mice. Transplantation 1980;29:308-13.

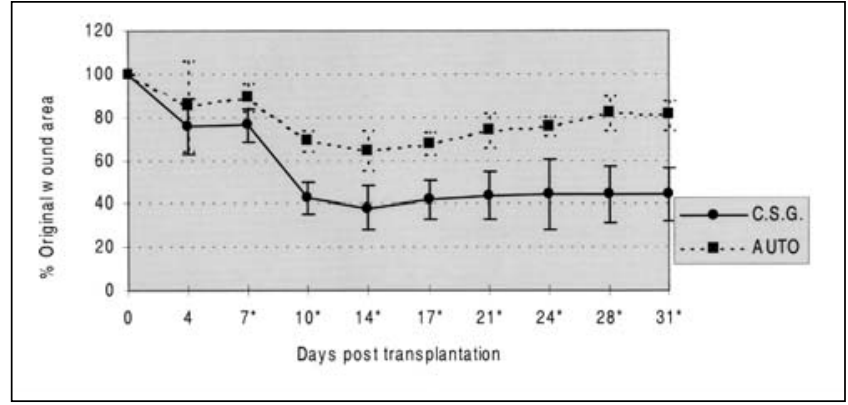

Figure 1) Percentage of original wound area after transplantation of composite skin graft (CSG) $(n=5)$ and autograft (auto) $(n=3)$. * Statistically significant

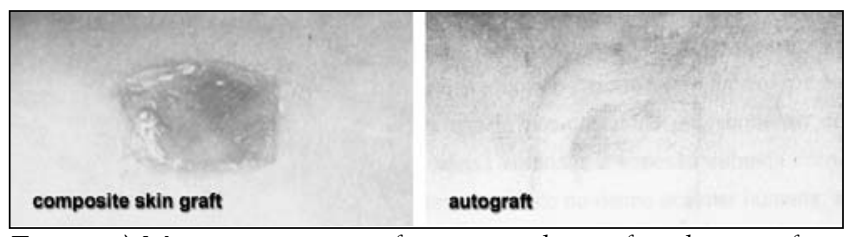

Figure 2) Macroscopic aspect of composite skin graft and autograft

Data presented in this experiment showed that the contraction of the composite skin graft and autograft was bigger after the dressings were removed at seven days after transplantation, and was bigger in composite skin graft than in autograft. This could be explained by self-injury by the mice and the trauma against the cage. After contraction between seven and 10 days after transplantation, there was a stable phase until the end of the experiment.

The limitation of skin substitute use for definitive coverage of large wounds with no donor sites is the need to evaluate the graft take.

The experiment data suggested that the contraction appeared after dressing removal, but that the macroscopic aspect of the composite skin graft remained normal with no distortion of the graft or the surrounded murine skin.

ACKNOWLEDGEMENTS: Financial support was received from Coordenação de aperfeiçoamento de pessoal de nível superior.

7. Billingham RE, Reynolds J. Transplantation studies on sheet of pure epidermal epithelium and of epidermal cell suspensions. Br J Plast Surg 1952;23:25-36.

8. Medalie DA, Tompkins RG, Morgan JR. Evaluation of acellular human dermis as a dermal analog in a composite skin graft. Asaio J 1996;42:1-8.

9. Boyce ST, Foreman TJ, English KB, et al. Skin wound closure in athymic mice with cultured human cells, biopolymers, and growth factors. Surgery 1991;110:866-76.

10. Boyce ST, Supp AP, Harriger MD, Greenhalgh DG, Warden GD. Topical nutrients promote engraftment and inhibit wound contraction of cultured skin substitutes in athymic mice. J Invest Dermatol 1995;104:345-9.

11. Boyce ST, Supp AP, Harriger MD, Pickens WL, Wickett RR, Hoath SB. Surface electrical capacitance as a noninvasive index epidermal barrier in cultured skin substitutes in athymic mice. J Invest Dermatol 1996;107:82-7. 